удК 349.2

DOI https://doi.org/10.32837/apdp.v0i86.2438

B. О.Рудяк

\title{
КЛАСИФІКАЦІЯ ОСІБ, ЯКІ ПОТРАПИЛИ У СКЛАДНІ ЖИТТЕВІ ОБСТАВИНИ
}

Розглядаючи проблему соціального забезпечення осіб, які потрапили у складні життєві обставини, відзначимо, що сьогодні досить актуальним питанням є правильне визначення такого кола осіб, оскільки саме такі особи підпадають під різноманітні соціальні програми, потребують відповідного соціального супроводу з боку уповноважених на те органів державної влади та місцевого самоврядування. Чітке визначення кола осіб, які перебувають у складних життєвих обставинах, є досить важливим не тільки для надання їм своєчасної державної соціальної допомоги, соціальної підтримки тощо, а й запобігання виникнення критичних ситуацій, які можуть бути пов'язані із життям та здоров'ям як особи, яка потрапила в такі складні обставини, так і осіб, які можуть перебувати поряд з такою особою. Йдеться, наприклад, про запобігання суїциду особи, відмову матері від дитини одразу після народження, запобігання жорстокому або такому, що принижує честь та гідність, поводженню по відношенню до особи, виявлення та відібрання дитини у сім’ї, де їй загрожує небезпека з боку батьків та інших осіб, які їх заміняють, вилучення дітей із неблагополучних сімей, де батьки про своїх дітей не піклуються або ж зловживають алкогольними напоями чи наркотичними засобами тощо. I такі приклади різноманітних негативних ситуацій ми щодня спостерігаємо з екранів телевізора, інтернет-новин, різноманітних засобів масової інформації, а історії про осіб, які потрапили в складні життєві обставини, чи членів їх сімей просто вражають. Досить часто з першого погляду ситуації, в які потрапляють окремі особи, є досить простими, незначними, проте кінець таких історій часто буває трагічним. Це пов'язано із психологічним та моральним здоров'ям людини, рівнем сприйняття ситуації, в яку вона потрапила, рівнем підтримки з боку інших близьких осіб тощо.

Водночас одним із ключових аспектів запобігання негативним наслідкам відносно осіб, які потрапили у складні життєві обставини, є своєчасне реагування відповідних органів державної влади, до компетенції яких віднесено здійснення державної політики у соціальній сфері. Логічно, що реагування є можливим тільки щодо осіб, які перебувають на відповідному обліку у соціальних служббах чи про яких відомі такі обставини, які становлять загрозу для особи чи членів їі сім'ї.

Загалом проблемою соціального захисту населення, в тому числі й дослідженням осіб, які перебувають у складних життєвих обставинах, займались такі науковці, як Ю.М. Бондаренко, Ф.М. Бородкіна, Ф.Е. Василюк, І.В. Ващенко, О.С. Власюк, К.В. Денисенко, І.П. Дацюк, Б.Б. Іваненко, В.В. Лаврухін, В.О. Лактінов, В.М. Литвиненко, В.В. Мамонова, І.В. Матюрін, К.С. Міщенко, Л.Ю. Новикова, І.В. Рудкевич та інші. Проте, попри ряд проведених досліджень у вказаній 
сфері, зазначимо, що чинним законодавством не визначено чіткого та вичерпного переліку осіб, які перебувають у складних життєвих обставинах, а це значно ускладнює роботу відповідних органів державної влади щодо своєчасного їх виявлення, а отже, й надання соціальної чи інших видів допомоги. Лише окремими законами визначено категорії осіб, які можуть перебувати у зоні ризику як особи, які перебувають у складних життєвих обставинах. Законом України «Про соціальні послуги» надано таке визначення вразливих груп населення: це особи / сім'ї, які мають найвищий ризик потрапляння у складні життєві обставини через вплив несприятливих зовнішніх та/ або внутрішніх чинників [1]. Цим же законом передбачені чинники, які можуть зумовити складні життєві обставини: а) похилий вік; б) часткова або повна втрата рухової активності, пам'яті; в) невиліковні хвороби, хвороби, що потребують тривалого лікування; г) психічні та поведінкові розлади, у тому числі внаслідок вживання психоактивних речовин; г) інвалідність; д) бездомність; е) безробіття; є) малозабезпеченість особи; ж) поведінкові розлади у дітей через розлучення батьків; з) ухилення батьками або особами, які їх замінюють, від виконання своїх обов'язків із виховання дитини; и) втрата соціальних зв'язків, у тому числі під час перебування в місцях позбавлення волі; і) жорстоке поводження з дитиною; ї) насильство за ознакою статі; й) домашне насильство; к) потрапляння в ситуацію торгівлі людьми; л) шкода, завдана пожежею, стихійним лихом, катастрофою, бойовими діями, терористичним актом, збройним конфліктом, тимчасовою окупацією. Аналізуючи норми вказаного закону, можемо констатувати, що якщо щодо особи виникає хоча б один із вищевказаних чинників, і особа самостійно не може подолати такі обставини, можна вважати, що особа потрапила у складні життєві обставини.

Про подібні обставини, які впливають на визначення особи такою, що потрапила в складні життєві обставини, вказано й у іншому нормативно-правовому акті - Порядку виявлення сімей (осіб), які перебувають у складних життєвих обставинах, надання їм соціальних послуг та здійснення соціального супроводу таких сімей (осіб), затвердженого постановою Кабінету Міністрів України від 21 листопада 2013 р. № 896. Цим же порядком передбачено й категорії осіб, яких віднесено до потенційних отримувачів соціальних послуг, до яких належать сім'ї:

1) членами яких є: одинока матір (батько); діти, розлучені із сім'єю, які не є громадянами України і заявили про намір звернутися до компетентних органів із заявою про визнання біженцем; інваліди та діти-інваліди; особи, у тому числі діти, які постраждали від насильства, жорстокого поводження та торгівлі людьми; батьки, у яких діти відібрані без позбавлення батьківських прав; батьки, які подали заяву про розлучення або перебувають у процесі розлучення; батьки - трудові мігранти; засуджені до покарання у виді обмеження волі або позбавлення волі на певний строк, або особи, що повернулися з місць позбавлення волі або перебувають у місцях попереднього ув'язнення;

2) опікунів (піклувальників) дітей, розлучених із сім'єю;

3) у яких діти перебувають в інтернатних закладах або оформляються до них;

4) що виявили намір відмовитися від новонародженої дитини [2].

В той же час наголосимо на тому, що вказаний перелік отримувачів соціальних послуг повною мірою не охоплює категорію тих осіб та сімей, які потрапили 
в складні життєві обставини, а тому перелік осіб, яких ми досліджуємо, є набагато більшим. Так, у вищенаведеній нормі не враховано такі категорії осіб, як учасники АТО та члени їх сімей; сім’ї, які мають у своєму складі особу інваліда; сім’ї, де є тяжко хворі, малозабезпечені, неблагополучні сім’ї тощо.

Переходячи до безпосереднього розгляду та здійснення класифікації осіб, які перебувають у складних життєвих обставинах, зазначимо, що відповідно до Конституції України - Україна є соціальною державною. Стаття 3 Основного Закону нашої держави проголошує, що людина, іï життя, честь та гідність, недоторканість і безпека визнаються в Україні найвищою соціальною цінністю. Права і свободи людини та їх гарантії визначають зміст та спрямованість діяльності держави. Держава відповідає перед людиною за свою діяльність. Утвердження та забезпечення прав і свобод людини є головним обов'язком держави [3]. Враховуючи вищенаведені норми соціальний захист в Україні розповсюджується не тільки на громадян України, а й на іноземців та осіб без громадянства. Ця норма стосується й питання надання соціальної допомоги особам, які перебувають у складних життєвих обставинах. Як вказує Ю.В. Попик, відповідно до чинного законодавства України будь-які особи, які перебувають на території України на законних підставах та опинилися у складних життєвих обставинах, мають право на отримання соціальних послуг. До потенційних користувачів соціальних послуг належать і громадяни інших країн, а також особи без громадянства та біженці, тобто особи, які отримали цей статус у встановленому законом порядку, а також передбачено, що сім'ї, діти і молодь, які опинилися у життєвій скруті, мають право на отримання соціальних послуг на безоплатній основі [4, с. 194]. Таким чином, до осіб, які перебувають у складних життєвих обставинах, віднесено не тільки громадян України, а й іноземців та осіб без громадянства, проте за умови їх законного перебування на території України. Іноземці та особи без громадянства користуються однаковими соціальними правами нарівні з громадянами України, а тому у разі виникнення обставин, які останні не можуть самостійно подолати, вони можуть розраховувати на допомогу з боку держави, на території якої вони перебувають. Таким чином, за правовим взаємозв'язком із громадянством України, осіб, які перебувають у складних життєвих обставинах, можна поділити на: 1) громадяни України; 2) іноземці; 3) особи без громадянства. Крім того, не можна недооцінювати й таку категорію осіб, як біженці.

Наступною класифікацією осіб, які перебувають у складних життєвих обставинах, ми пропонуємо здійснювати за кількістю суб'єктів: 1) одна особа, тобто це один суб’єкт, який потрапив у складні життєві обставини. Це може бути, наприклад, конкретна особа, одинока особа; 2) дві і більше особи, які не пов'язані між собою родинними чи іншими зв'язками; 3) сім'я. Якщо першими двома категоріями все зрозуміло, то остання категорія - сім'я - потребує більш детального дослідження та аналізу. Отже, важливим з нашого погляду є дослідження сім'ї як окремої соціальної категорії, до складу якої можуть входити як сукупність осіб, так і конкретно визначена особа, яка підпадатиме під категорію осіб, які перебувають у складних життєвих обставинах. Тобто в контексті дослідження пропонуємо розглядати як сім'ю загалом, яка перебуває у складній життєвій ситуації, так і окремого ії члена. Загалом під термінологічним розумінням поняття «сім’я» розуміють осіб, які спільно проживають, пов’язані спільним побутом, мають взаємні права й обов'язки. Сім'я, яка належним чином виконує 
свої функції, називається здоровою, ії основними ознаками є: згуртованість; відкритість для встановлення нових стосунків; оптимізм і турбота; здатність самостійно вирішувати завдання свого розвитку; ідентичність. Сім'я виступає провідним чинником соціалізації особистості на макрорівні [5, с. 129]. У разі відсутності вказаних ознак чи більшості з них сім'я може вважатися неблагополучною, а у разі наявності ще й певних обставин, які особа не може вирішити самостійно, - такою, що перебуває у складних життєвих обставинах. В той же час не можна співвідносити неблагополучні сім'ї із сім'ями, які перебувають у складних життєвих обставинах, оскільки не кожна сім'я, яка перебуває у складних життєвих обставинах, є неблагополучною. Проте водночас на практиці досить часто можна спостерігати зворотну ситуацію. Значна кількість сімей, які є неблагополучними та стоять на обліку у відповідних соціальних службах, перебувають у складних життєвих ситуаціях, що зумовлено способом їхнього життя, відсутністю роботи, стабільного доходу, працездатності тощо.

Загалом сім'ї, які перебувають у складних життєвих обставинах, можна розподілити на такі види: 1) сім'ї з дітьми; 2) сім'ї, у яких є особи з інвалідністю, в тому числі й дитина-інвалід; 3) сім’ї, у яких хтось із членів сім'ї споживає алкогольні напої чи наркотичні засоби; 4) сім' ї, проблеми яких зумовлені в основному внутрішнім сімейним конфліктом між членами сім'ї. Характерною рисою вказаних сімей, на думку М.А. Галагузова, є те, що сім'ї у складних життєвих обставинах мають низький соціальний статус у якій-небудь зі сфер життєдіяльності чи в кількох водночас, вони не справляються з покладеними на них функціями, їх адаптивні здібності суттєво знижені [6, с. 76].

Наступним критерієм для класифікації сімей у складних життєвих обставинах є критерій повноти сім’ї. Так, за повнотою (кількістю членів, які входять до сім'ї) сім’ї поділяють: 1) повні сім'ї; 2) неповні сім'ї, в тому числі й у разі, коли один із батьків позбавлений батьківських прав у зв'язку із невиконанням своїх обов'язків по відношенню до дітей. До неповних сімей віднесено сім'ї, де жінка (чоловік) виховує дитину сама (сам), без чоловіка (жінки). Зазначимо, що проблема можливості виховання та забезпечення матір'ю своєї дитини самостійно є досить обговорюваною та поширеною проблемою.

Класифікація осіб, які потрапили в складні життєві обставини, може здійснюватись й за іншими критеріями. Наприклад, за рівнем доходу: 1) особи із нормальним (звичайним) достатком, тобто це ті особи, які відповідно до норм чинного законодавства не віднесені до категорії малозабезпечених, проте в окремий період перебувають у складних життєвих обставинах та не можуть їх самостійно подолати; 2) малозабезпечена особа, тобто та, яка набула вказаного статусу в органах соціального захисту. У Законі України «Про соціальні послуги» під малозабезпеченою особою розуміється - особа, середньомісячний сукупний дохід якої за останніх шість календарних місяців, що передують місяцю звернення за наданням соціальних послуг, не перевищує двох прожиткових мінімумів для відповідної категорії осіб. Середньомісячний сукупний дохід особи обчислюється шляхом ділення середньомісячного сукупного доходу їі сім'ї на кількість членів сім'ї, які включаються до її складу. Методика обчислення середньомісячного сукупного доходу сім'ї затверджується центральним органом виконавчої влади, що забезпечує формування державної політики у сфері соціального захисту населення. 
До інших критеріїв класифікації осіб, яка перебувають у складних життєвих обставинах, варто віднести такі:

- за суб'єктами: 1) учасники АТО та їх сім'ї; 2) внутрішньо переміщені особи; 3) жінки, які виявили намір або мають ризик відмови від новонародженої дитини; 4) жінки, які потерпають від домашнього насильства; 5) молодь та неповнолітні, які засуджені до покарання без позбавлення волі; 6) особи з числа багатодітних сімей; 7) особи з числа неповних сімей тощо;

- за територіальним принципом пропонуємо виділяти: 1) біженців; 2) внутрішньо переміщених осіб. Вважаємо, що біженці та внутрішньо переміщені особи не є тотожними категоріями, оскільки мають різний соціальний статус;

- за об'єктивними причинами, які стали передумовою виникнення в особи чи іï сім’ї складної життєвої ситуації. Тобто у вказаному аспекті враховуються ті причини, які поставили особу у складну життєву ситуацію, яка не залежала від волі самої людини. До таких категорій осіб варто віднеси: 1) осіб, які стали жертвами політичних переслідувань та політичних репресій; 2) осіб, які стали жертвами збройних конфліктів; 3) осіб, які стали жертвами домашнього насильства, тощо;

- за станом здоров'я: 1) працездатні особи; 2) громадяни, які не здатні до самообслуговування у зв'язку з похилим віком, хворобою, інвалідністю іншими причинами, які пов'язані із станом здоров'я особи;

- за рівнем працездатності: 1) працездатні особи; 2) непрацездатні особи;

- за наявністю трудових відносин: 1) особи, які працевлаштовані офіційно; 2) особи, які працевлаштовані неофіційно; 3) особи, які перебувають на обліку в центрі занятості як такі, що шукають роботу, тобто офіційно мають статус безробітного; 4) особи, які не мають офіційного статусу безробітного;

- за наявністю житла: 1) особи, які перебувають у складних життєвих обставинах та мають власне житло; 2) бездомні особи. Як зазначає А.О. Медвідь, до категорії бездомних належать такі особи: особи, які постраждали від торгівлі людьми, катастроф та нещасних випадків, мігранти, інваліди, особи пенсійного віку, особи, які відбули покарання у виді обмеження волі або позбавлення волі на певний строк, особи, які втратили житло у зв'язку із сімейними обставинами, пов'язаними з конфліктами та насильством у сім'ї. Особливої уваги потребують особи, які належать до груп ризику щодо втрати житла або права на його використання, зокрема, діти-сироти та діти, позбавлені батьківського піклування, мешканці гуртожитків, для яких таке житло є єдиним місцем проживання, особи, які не мають власного житла та проживають в орендованих приміщеннях, у знайомих, родичів, друзів, а також особи, які страждають на психічні розлади, хворі на наркоманію та хронічний алкоголізм, недієздатні та обмежено дієздатні особи [7, с. 8 ].

Як висновок зазначимо, що особи, які потрапили в складні життєві обставини, характеризуються своєю різноманітністю, а тому перелік таких осіб є відкритим та 3 кожним роком може доповнюватися відповідно до рівня та розвитку суспільних відносин у соціальній сфері. Класифікувати таких осіб можна за різноманітними підставами, які загалом розкривають сутність вищевказаних категорій осіб та за допомогою яких здійснюється більш детальне вивчення осіб, які перебувають у складних життєвих обставинах та проводиться їх повноцінне дослідження. 


\section{Jimepamypa}

1. Про соціальні послуги: Закон України від 17.01.2019 № 2671-VIII. Офіційний вісник Украӥни. 2019. № 34. Стор. 107. Стаття 1199.

2. Про затвердження Порядку виявлення сімей (осіб), які перебувають у складних життєвих обставинах, надання їм соціальних послуг та здійснення соціального супроводу таких сімей (осіб): постанова Кабінету Міністрів України від 21 листопада 2013 р. № 896. Офіиійний вісник України. 2013. № 98. Стор. 17. Стаття 3609.

3. Конституція України від 28.06.1996 № 254к/96-ВР. Офіційний вісник України. 2010. № 72/1 Спеціальний випуск. Стор. 15. Стаття 2598.

4. Попик Ю.В. Організація діяльності інтегрованих соціальних служб і територіальних громадах. Науковий вісник ужгородського ун-ту. Серія «Педагогіка, соціальна робота». 2016. Вип. 2 (39). С. 193-196.

5. Технології соціально-педагогічної роботи : навч. посіб. За ред. А.Й. Капської. Київ, 2000. 372 с.

6. Галагузова М.А. Социальная педагогика : курс лекций. Москва : Гуманит. изд. центр ВЛАДОС, $2000.416 \mathrm{c}$.

7. Медвідь А.О. Соціальний захист бездомних осіб і безпритульних дітей. Дисертація на здобуття наукового ступеня кандидата юридичних наук за спеціальністю 12.00 .05 - трудове право; право соціального забезпечення. - Національний університет «Одеська юридична академія». Одеса. 2015. $23 \mathrm{c.}$

\section{Анотація}

Рудяк В. О. Класифікація осіб, які потрапили у складні життєві обставини. - Стаття.

У статті здійснено розгляд осіб, які потрапили в складні життєві обставини, у контексті їх нормативно-правового закріплення та наукового дослідження. Наголошено на тому, що чинним законодавством не визначено чіткого та вичерпного переліку осіб, які перебувають у складних життєвих обставинах, а це значно ускладнює роботу відповідних органів державної влади щодо своєчасного їх виявлення, а отже, й надання соціальної чи інших видів допомоги.

Авторкою проаналізовано Закон України «Про соціальні послуги», зауважено, що цим же законом передбачені чинники, які можуть зумовити складні життєві обставини: а) похилий вік; б) часткова або повна втрата рухової активності, пам'яті; в) невиліковні хвороби, хвороби, що потребують тривалого лікування; г) психічні та поведінкові розлади, у тому числі внаслідок вживання психоактивних речовин; г) інвалідність; д) бездомність; е) безробіття тощо. Науковицею розглянутий «Порядок виявлення сімей (осіб), які перебувають у складних життєвих обставинах, надання їм соціальних послуг та здійснення соціального супроводу таких сімей (осіб)», який затверджений постановою Кабінету Міністрів України від 21 листопада 2013 р. № 896. Під час безпосереднього розгляду та здійснення класифікації осіб, які перебувають у складних життєвих обставинах, автором розглядається стаття 3 Конституції України та зосереджується увага на тому, що Україна є соціальною державною. У статті здійснено класифікацію осіб, які потрапили у складні життеві обставини за різноманітними підставами, зокрема: за правовим взаємозв'язком із громадянством України; за кількістю осіб (суб'єктів); за суб'єктами; за територіальним принципом; за рівнем доходу особи; за об'єктивними причинами, які стали передумовою виникнення в особи чи її сім'ї складної життєвої ситуації; за станом здоров'я; за наявністю житла тощо. Особливу увагу приділено сім’ї як окремій соціальній категорії. Важливим з погляду науковиці є дослідження сім'ї як окремої соціальної категорії, до складу якої можуть входити як сукупність осіб, так і конкретно визначена особа, яка підпадатиме під категорію осіб, які перебувають у складних життєвих обставинах.

Ключові слова: складні життєві обставини, сім’я, особа, соціальна допомога, класифікація.

\section{Summary}

Rudyak V.O. Classification of persons who found themselves in difficult life circumstances. - Article.

The article examines persons who find themselves in difficult life circumstances in the context of their legal consolidation and research. It is emphasized that the current legislation does not define a clear and exhaustive list of persons in difficult life circumstances, which significantly complicates the work of relevant public authorities to identify them in a timely manner, and thus provide social or other assistance.

The author analyzes the Law of Ukraine "On Social Services", noting that the same law provides for factors that can cause difficult life circumstances: a) old age; b) partial or complete loss of motor 
activity, memory; c) incurable diseases, diseases that require long-term treatment; d) mental and behavioral disorders, including due to the use of psychoactive substances; e) disability; e) homelessness; f) unemployment, etc. The scientist considered the "Procedure for identifying families (persons) who are in difficult life circumstances, providing them with social services and providing social support to such families (persons)", which was approved by the Cabinet of Ministers of Ukraine dated November 21, 2013 № 896. and the classification of persons in difficult life circumstances, the author considers Article 3 of the Constitution of Ukraine and focuses on the fact that Ukraine is a social state. The article classifies persons who have found themselves in difficult life circumstances on various grounds, in particular: by legal relationship with the citizenship of Ukraine; by the number of persons (subjects); by subjects; according to the territorial principle in respect of which difficult life circumstances arose; by the level of income of the person; for objective reasons, which became a prerequisite for the emergence of a person or his family in a difficult life situation; for health reasons; by availability of housing, etc. Special attention is paid to the family as a separate social category. It is important, from the scientist's point of view, to study the family as a separate social category and which may include both a set of persons and a specific person who will fall into the category of persons in difficult life circumstances.

Key words: difficult life circumstances, family, person, social assistance, classification. 